\title{
A review of the ergot alkaloids found in endophyte-infected tall fescue and perennial ryegrass and their metabolism after ingestion by livestock
}

\author{
J. M. DURINGER ${ }^{1}$, M. J.M. DELORME ${ }^{1}$, A. LEHNER ${ }^{2}$ and A. M. CRAIG ${ }^{3}$ \\ ${ }^{I}$ Department of Environmental and Molecular Toxicology, College of Agricultural Sciences, \\ Oregon State University, Corvallis OR, USA \\ ${ }^{2}$ College of Agriculture, Livestock Disease Diagnostic Center, University of Kentucky, Lexington KY, USA \\ ${ }^{3}$ College of Veterinary Medicine, Oregon State University, Corvallis OR, USA \\ Jennifer.Duringer@oregonstate.edu
}

\begin{abstract}
Tall fescue (Festuca arundinacea) and perennial ryegrass (Lolium perenne) are perennial cool-season grasses which are infected with the endophytic fungi, Neotyphodium coenophialum and $N$. lolii, respectively. These endophytes have been increasingly selected for, as they confer benefits such as pest resistance and drought tolerance to the plant. However, livestock grazing endophyte-infected $(\mathrm{E}+)$ grasses are negatively impacted by fungal ergot and lolitrem alkaloids, which are responsible for a variety of mammalian diseases including fescue toxicosis (summer syndrome, fescue foot and fat necrosis) and ryegrass staggers. Most likely, not all of the ergot alkaloids involved in fescue toxicosis have been identified to date. During sample processing for the diagnostic analysis of the endophyte toxin ergovaline, other unidentified peaks occasionally elute that appear to coincide with clinical disease. Analysis of unidentified chromatographic peaks was performed on feed samples by LCMS/MS to determine their chemical structures and identities. Ergotamine, ergovaline, ergocornine, ergonovine, ergocryptine, ergocrystine and lysergol appeared in various samples and matched controls. Newly identified compounds included ergosine, ergostine and ergoptine. In addition, several samples showed one or more of fourteen new ergots ranging in size from 381-611 mw, with key mass spectral characteristics of ergot alkaloidsspecifically, m/z 223 and 208 corresponding to the ergoline ring system and its demethylated variant, respectively. Once ingested, ergot alkaloids are thought to be metabolised in the rumen and/ or liver of livestock species. Ruminal metabolism of ergovaline was studied in sheep offered Neotyphodium coenophialuminfected tall fescue straw at two ergovaline levels $(<10 \mathrm{ppb}$ and
\end{abstract}

$500 \mathrm{ppb}$ ) for 28 days. Ergovaline concentration in rumen fluid expressed as a percent of intake increased over sampling time and sampling day $(\mathrm{P}<0.05)$. Lysergic acid concentration in rumen fluid expressed as a percent of intake increased over time from day 0 to day $3(\mathrm{P}<0.05)$ but was not different between day 3 and day 28 at any time point $(\mathrm{P}>0.10)$. The faeces contained an average of $0.41 \mu \mathrm{mol} /$ day ergovaline and $0.87 \mu \mathrm{mol} /$ day lysergic acid. Urine contained no detectable ergovaline; lysergic acid concentration was $0.213 \mu \mathrm{mol} / \mathrm{day}$. The appearance of lysergic acid in the faeces, urine and rumen fluid is most likely due to the degradation of ergovaline in the rumen from microbial degradation and further break down in the lower digestive tract. Hepatic metabolism was studied using a mouse model, where the in vitro metabolism of ergotamine in mouse liver microsomes was characterised by LC-MS/MS. Microsomal incubations produced nine predominate peaks which were confirmed to be ergotamine, ergotamine epimer, monohydroxylated metabolites (M1, M2, M1e, M2e) and dihydroxylated metabolites (M3, M4, M5).

Keywords: tall fescue, perennial ryegrass, endophyte, ergot alkaloids, metabolism, livestock

\section{Introduction}

The grass seed industry in the Pacific Northwest provides over $70 \%$ of the world's supply of tall fescue (Festuca arundinacea) and perennial ryegrass (Lolium perenne) seed, contributing \$374 million (farm gate value) to the state's economy each year (Oregon Agricultural Information Network 2006). As pressure developed to end field burning as a method of straw/hay disposal in Oregon in the 1980s, producers sought to develop an alternative market. Fortunately, grass straw/hay is a nutritious food resource $(6-7 \%$

Figure 1 General structure of the ergot alkaloids. R1 and R2 alkyl and aralkyl substituents are listed with corresponding compound names.

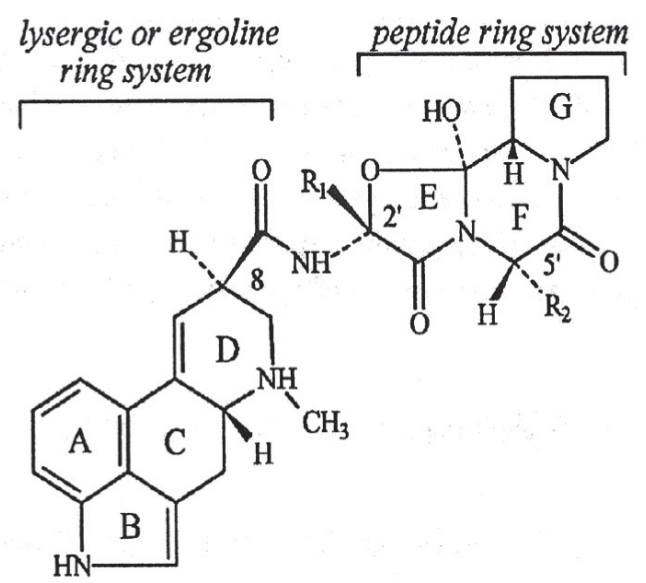

\begin{tabular}{lll}
\hline $\mathrm{R} 1$ & $\mathrm{R} 2$ & Compound \\
\hline $\mathrm{CH}_{3}$ & $\mathrm{CH}\left(\mathrm{CH}_{3}\right)_{2}$ & Ergovaline \\
$\mathrm{CH}_{3}$ & $\mathrm{CH}_{2} \mathrm{C}_{6} \mathrm{H}_{5}$ & Ergotamine \\
$\mathrm{CH}\left(\mathrm{CH}_{3}\right)_{2}$ & $\mathrm{CH}\left(\mathrm{CH}_{3}\right)_{2}$ & Ergocornine \\
$\mathrm{CH}\left(\mathrm{CH}_{3}\right)_{2}$ & $\mathrm{CH}_{2} \mathrm{CH}_{2}\left(\mathrm{CH}_{3}\right)_{2}$ & Ergocryptine \\
$\mathrm{CH}\left(\mathrm{CH}_{3}\right)_{2}$ & $\mathrm{CH}_{2} \mathrm{C}_{6} \mathrm{H}_{5}$ & Ergocrystine \\
Other C-8 substitutions (i.e. in place of peptide-NHC=O): \\
$(\mathrm{C}=\mathrm{O}) \mathrm{NHC}\left(\mathrm{CH}_{3}\right) \mathrm{CH}_{2} \mathrm{OH}$ & Ergonovine \\
$\mathrm{COOH}$ & & Lysergic acid \\
$\mathrm{CH}$ & & Lysergol \\
$(\mathrm{C}=\mathrm{OH}) \mathrm{NH}_{2}$ & & Ergine \\
\hline
\end{tabular}


Figure 2 A-J Mass spectral analysis of ergotamine and its microsomal transformation products collected by preparative HPLC. Ergotamine (A) and ergotamine epimer (B) were resolved by MS. Monohydroxylated metabolites were resolved by MS (metabolite 1 (2C)) and MS/MS at m/z 598 (metabolite M1 epimer (2D), metabolite M2 (2E), metabolite M2 epimer (2F)). Dihydroxylated metabolites were resolved by MS (metabolite M5 (2G)) and MS/MS at m/z 614 (metabolite M4 (2H) and metabolite M3 (2I)). 2J: Chemical structure of ergotamine. C8' and C9'of the peptide ring identify hypothesised sites of hydroxylation.
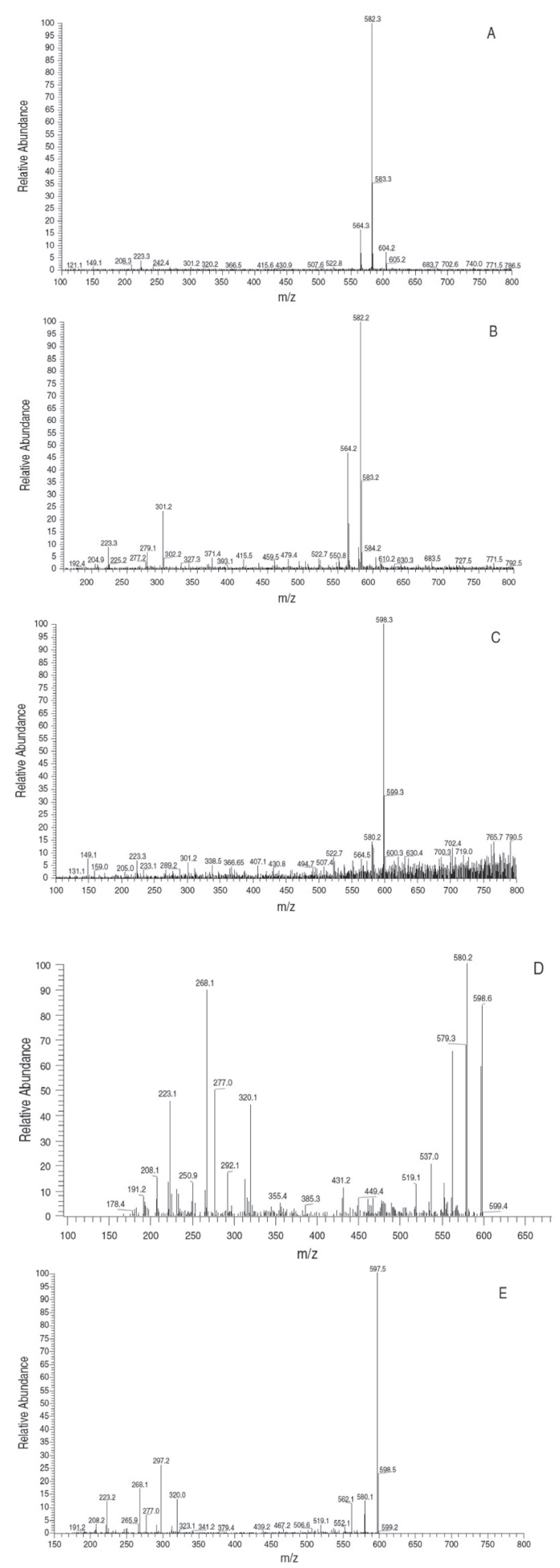
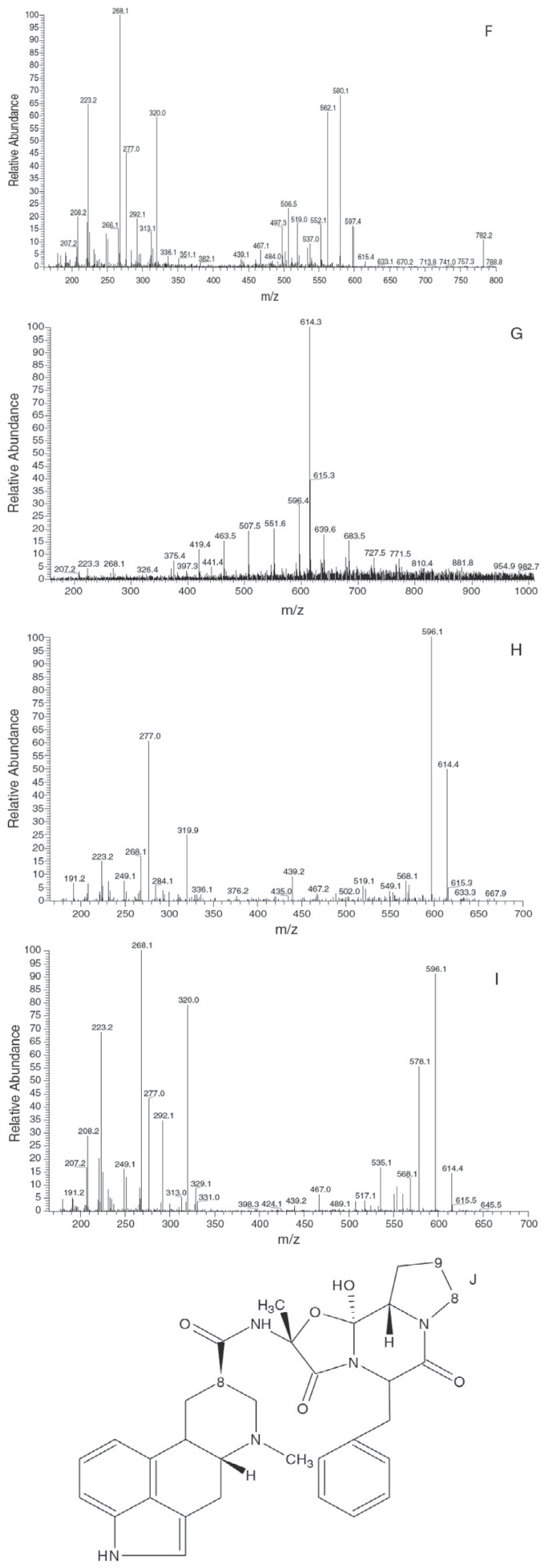
Table 1 Known ergot alkaloids found in straw samples by HPLC-two phase MRM.*

\begin{tabular}{|c|c|c|c|c|c|c|c|c|c|c|}
\hline Sample & $\begin{array}{l}\text { Ergotamine } \\
\text { (mw 581) }\end{array}$ & $\begin{array}{l}\text { Ergovaline } \\
\text { (mw 533) }\end{array}$ & $\begin{array}{l}\text { Ergocornine } \\
\text { (mw561) }\end{array}$ & $\begin{array}{l}\text { Ergonovine } \\
\text { (mw 325) }\end{array}$ & $\begin{array}{l}\text { Ergocryptine } \\
\text { (mw 575) }\end{array}$ & $\begin{array}{l}\text { Ergocrystine } \\
\text { (mw 609) }\end{array}$ & $\begin{array}{l}\text { Lysergol } \\
\text { (mw 254) }\end{array}$ & $\begin{array}{l}\text { Ergosine } \\
\text { (mw 548) }\end{array}$ & $\begin{array}{l}\text { Ergostine } \\
\text { (mw 387) }\end{array}$ & $\begin{array}{l}\text { Ergoptine } \\
\text { (mw 561) }\end{array}$ \\
\hline \#154 & $x$ & $X$ & $X$ & $X$ & $x$ & $x$ & & $X$ & $x$ & \\
\hline \#171 & $x$ & & $X$ & & & & & & & \\
\hline \#3250 & $x$ & & & & & & & & & \\
\hline \#4646-1 & $x$ & & $X$ & $x$ & $x$ & $x$ & & $x$ & & \\
\hline \#4646-2 & $X$ & $X$ & $x$ & $x$ & $x$ & $x$ & & $X$ & & \\
\hline \#4682 & $X$ & $x$ & & & & & $X$ & & & \\
\hline \#4687 & $x$ & & & & & & & & & \\
\hline \#4689 & $x$ & & & & & & & & & \\
\hline \#4714 & $X$ & $X$ & $x$ & & & & & & & \\
\hline \#4794 & $x$ & & & & & & & & & \\
\hline \#9 & $x$ & $x$ & $x$ & $x$ & $x$ & $x$ & & & & $x$ \\
\hline
\end{tabular}

* Ergotamine through lysergol were confirmed in samples with available standards; the other ergot alkaloids were projected based on molecular weight descriptions from the literature.

protein) for livestock, particularly for sheep, cattle, and llamas. Marketing of this material produces an additional $\$ 80$ million yearly in income for the state, mainly as an export to Japan and other Pacific Rim countries (Oregon Ag Fiber Association, pers. comm.). To combat insect predation and to produce more vigorous, drought-resistant plants, endophytic fungi have been deliberately promoted in both tall fescue and perennial ryegrass varieties (Neotyphodium coenophialum in tall fescue and N. lolii in perennial ryegrass). Endophytes exert these benefits through the production of ergot and/or lolitrem alkaloids. Unfortunately, these alkaloids also cause deleterious effects in cattle and other herbivore species when endophyte-infected grasses are grazed or fed as hay (Joost 1995; Porter 1995; Oliver 2005). Fescue foot or summer syndrome, ryegrass staggers, and reproductive problems caused by these plant toxins cause $\$ 1$ billion in livestock losses annually in the United States alone (Browning 2004). Thus, research on the toxic effects to animals and potential solutions comprises one of the most important research problems in foragelivestock interactions (Hoveland 1993).

Studies have been conducted previously to determine the ergot alkaloids found in grasses (Bacon 1988; Yates \& Powell 1988; Cheeke 1995; Porter 1995; Lane et al. 1997; Shelby et al. 1997), yet none had done so as exhaustively as we have using the new method of atmospheric pressure ionisation (see Fig.1 for a listing of structures for the more common ergot alkaloids) (Lehner et al. 2004). Further, unknown peaks occasionally elute which appear to coincide with clinical disease during the routine processing of diagnostic samples for detection of the main ergot alkaloid toxin ergovaline, submitted to the College of Veterinary Medicine at Oregon State University (Lehner et al. 2005; Duringer et al. 2007). The identity of these peaks is investigated here. While some data exists on the metabolism of ergot alkaloids in humans and animal models (Maurer et al. 1982; Kanto 1983; Maurer et al. 1983; Ball et al. 1992; Ronca et al. 1996; Mas-Chamberlin et al. 1997), there is a paucity of information concerning their metabolic fate when ingested by livestock species (Jaussaud et al. 1998; Moubarak \& Rosenkrans 2000). Results from a feeding trial which quantified ergovaline and its metabolite lysergic acid in the rumen fluid, urine and faeces of fistulated sheep fed Neotyphodium coenophialum-infected tall fescue straw at two ergovaline levels $(<10 \mathrm{ppb}$ and $500 \mathrm{ppb})$ are presented (DeLorme et al. 2007). Lastly, we characterised the hepatic metabolism of ergotamine in mouse liver microsomes by LC-MS/MS (Duringer et al. 2005). As this information is the result of numerous studies conducted in our laboratory, it is presented here as a review.

\section{Identification of Ergot Alkaloids in Tall Fescue and Perennial Ryegrass}

During the routine analysis of feed samples for the presence of ergovaline, other previously unknown peaks occasionally (in 10$15 \%$ of samples) elute that appear to coincide with clinical disease. When LC-MS/MS analysis of feed samples associated with ergotoxin exposure was performed, some samples were shown to contain a complex array of ergot alkaloids (e.g. \#154) while others contained only one or a few ergot alkaloids (e.g. \#3250) (Table 1) (Lehner et al. 2005; Duringer et al. 2007). In addition, 14 previously unidentified ergot alkaloids were found in these feed samples when analysed by LC-MS/MS (Table 2). All unknown compounds had m/z 223 and 208 in the daughter ion scan, both distinguishing fragments of ergot alkaloids corresponding to the ergoline ring system and its demethylated variant, respectively. It is anticipated that these findings will provide impetus for future development of analytical methodology for these heretofore relatively rare ergot alkaloid species.

\section{Metabolism of Ergovaline in Sheep Fed Endophyte-Infected Tall Fescue}

The degradation of ergovaline and production of lysergic acid in the rumen of sheep offered Neotyphodium coenophialum-infected tall fescue straw at two ergovaline levels $(<10 \mathrm{ppb}$ and $500 \mathrm{ppb})$ was investigated (DeLorme et al. 2007). Six fistulated crossbred wethers $(56 \pm 3.0 \mathrm{~kg} \mathrm{BW})$ were used in a randomised crossover design. The experiment consisted of two 28-day feeding periods with a 14-day washout period in between. Feed, orts, and faeces were measured and analysed for $\mathrm{DM}, \mathrm{ADF}$, and $\mathrm{CP}$, and used to determine digestibilities. Feed and water intake were monitored 
Table 2 Hypothetical structures proposed to accommodate new ergot alkaloid molecular weights. *

\begin{tabular}{lllll}
\hline mw & 2' [or 5'] substituents & $5^{\prime}$ 'or 2'] substituents & $\mathrm{C} 12^{\prime}-\mathrm{C} 11^{\prime}$ disposition & $\mathrm{C}$-C10 disposition \\
\hline 513 & Methyl & Isopropyl- ${ }_{2}$ & $\mathrm{C}=\mathrm{C}$ & $\mathrm{C}=\mathrm{CH}$ \\
529 & Methyl & Butyl & $\mathrm{C}=\mathrm{C}$ & $\mathrm{C}=\mathrm{CH}$ \\
531 & Methyl & Butyl & $\mathrm{C}=\mathrm{C}$ & $\mathrm{CH}-\mathrm{CH}_{2}$ \\
543 & Isopropyl & Isopropyl & $\mathrm{C}=\mathrm{C}$ & $\mathrm{C}=\mathrm{CH}$ \\
545 & Isopropyl & Isopropyl & $\mathrm{C}=\mathrm{C}$ & $\mathrm{CH}-\mathrm{CH}_{2}$ \\
547 & Methyl & Butyl & $\mathrm{C}(\mathrm{OH})-\mathrm{CH}$ & $\mathrm{C}=\mathrm{CH}$ \\
557 & Isopropyl & Butyl & $\mathrm{C}=\mathrm{C}$ & $\mathrm{C}=\mathrm{CH}$ \\
559 & Isopropyl & Butyl & $\mathrm{C}=\mathrm{C}$ & $\mathrm{CH}-\mathrm{CH}_{2}$ \\
563 & Methyl & Benzyl & $\mathrm{C}=\mathrm{C}$ & $\mathrm{C}=\mathrm{CH}$ \\
577 & Isopropyl & Butyl & $\mathrm{C}(\mathrm{OH})-\mathrm{CH}$ & $\mathrm{CH}-\mathrm{CH}_{2}$ \\
591 & Isopropyl & Benzyl & $\mathrm{C}=\mathrm{C}$ & $\mathrm{C}=\mathrm{CH}$ \\
593 & Isopropyl & Benzyl & $\mathrm{C}=\mathrm{C}$ & $\mathrm{CH}-\mathrm{CH}_{2}$ \\
595 & Ethyl & Benzyl & $\mathrm{C}(\mathrm{OH})-\mathrm{CH}$ & $\mathrm{C}=\mathrm{CH}$ \\
611 & Isopropyl & Benzyl & $\mathrm{C}(\mathrm{OH})-\mathrm{CH}$ & $\mathrm{CH}-\mathrm{CH}_{2}$ \\
\hline
\end{tabular}

*Refer to Figure 1 for location of substituents. 2' or 5' substituents are based on those found in the literature; C12'C11' disposition refers to either normal hydroxylated $[\mathrm{C}(\mathrm{OH})-\mathrm{CH}]$ structure or dehydrated double bond $[\mathrm{C}=\mathrm{C}]$; $\mathrm{C} 9-\mathrm{C} 10$ disposition refers to normal $\mathrm{D}$-ring double bond $[\mathrm{C}=\mathrm{C}]$ or its hydrogenated alternative $[\mathrm{CH}-\mathrm{CH} 2]$.

Table 3 Ergovaline and lysergic acid concentration $(\mathrm{ng} / \mathrm{ml})$ in ruminal fluid of wethers consuming an endophyte-infected tall fescue diet with $0.610 \mathrm{mg} / \mathrm{kg}$ ergovaline.

\begin{tabular}{|c|c|c|c|c|c|}
\hline & \multirow[t]{2}{*}{ Time } & \multicolumn{3}{|c|}{---------- Day ---------- } & \multirow[b]{2}{*}{ SE } \\
\hline & & 0 & 3 & 28 & \\
\hline \multirow[t]{3}{*}{ Ergovaline } & $\mathrm{Oh}$ & $0.00^{a, x}$ & $4.26^{b, x}$ & $6.33^{c, x}$ & 0.585 \\
\hline & $6 \mathrm{~h}$ & $1.25^{\mathrm{a}, \mathrm{y}}$ & $4.44^{\mathrm{b}, \mathrm{x}}$ & $6.04^{c, x}$ & 0.688 \\
\hline & $12 \mathrm{~h}$ & $2.18^{a, z}$ & $5.17^{\mathrm{b}, \mathrm{x}}$ & $7.01^{c, x}$ & 1.13 \\
\hline SE & & 0.68 & 1.95 & 1.52 & \\
\hline \multirow[t]{3}{*}{ Lysergic acid } & $\mathrm{Oh}$ & $0.00^{a, x}$ & $7.08^{\mathrm{b}, \mathrm{x}}$ & $6.57^{\mathrm{b}, \mathrm{x}}$ & 0.643 \\
\hline & $6 \mathrm{~h}$ & $3.20^{\mathrm{a}, \mathrm{y}}$ & $9.02^{\mathrm{b}, \mathrm{x}}$ & $9.67^{\mathrm{b}, \mathrm{x}}$ & 2.78 \\
\hline & $12 \mathrm{~h}$ & $5.37^{a, y}$ & $10.1^{\mathrm{b}, \mathrm{x}}$ & $9.98^{b, x}$ & 1.68 \\
\hline SE & & 1.28 & 3.15 & 2.22 & \\
\hline
\end{tabular}

a,b,cWithin a row, means without a common superscript letter differ $(P<0.05)$.

$x, y, z$ Within a column, means without a common superscript letter differ $(P<0.05)$.

Table 4 Mass balance of ergovaline and lysergic acid ( $\mu$ mole) in wethers comsuming an endophyte-infected tall fescue diet $^{1}$.

\begin{tabular}{llll}
\hline & Ergovaline & Lysergic acid & Combined alkaloids $^{2}$ \\
\hline Intake, $\mu$ mole & $1.153 \pm 0.198$ & $0.155 \pm 0.031$ & $1.371 \pm 0.199$ \\
${\text { Excreted, } \mu \text { mole }^{3}}^{0.408 \pm 0.054}$ & $0.383 \pm 0.065$ & $0.791 \pm 0.092$ \\
Urine & & $0.213 \pm 0.082$ & $0.213 \pm 0.082$ \\
Feces & $0.408 \pm 0.054$ & $0.174 \pm 0.056$ & $0.582 \pm 0.088$ \\
Recovered, \% & 35.4 & 548 & 60.5 \\
\hline
\end{tabular}

${ }^{1} \mathrm{n}=6$; mean \pm standard deviation

${ }^{2} \mu$ moles of ergovaline plus $\mu$ moles of Iysergic acid

${ }^{3}$ Values for urine and faeces are combined 
throughout the feeding periods. Body weight and serum prolactin levels (collected prior to feeding via jugular venipuncture) were measured at the start and end of each feeding period. Ruminal fluid was sampled with a rumen suction strainer 3 times (days 0,3, and 28) during each 28-d feeding period for ergovaline and lysergic acid. Samples were collected at 0 (before feeding), 6 and 12 hours post-feeding. Total faecal and urine collection (via faecal bags or collection in plastic pans, respectively, each changed out twice in a 24-hour period) commenced on day 21 and continued until day 25 of each feeding period.

Digestion of DM, ADF and CP were not different between treatments $(\mathrm{P}>0.10)$. Daily water intake was reduced $(2.95 \mathrm{E}-\mathrm{vs}$. $2.771 / \mathrm{d} E+, \mathrm{SE} 0.06 ; \mathrm{P}<0.05)$, and serum prolactin was reduced by $72 \%(\mathrm{P}<0.05)$ on the $\mathrm{E}+$ diet which is consistent with clinical signs of fescue toxicosis. Ergovaline concentration in ruminal fluid increased over sampling days at each sampling time $(\mathrm{P}<0.05$, Table 3). Lysergic acid concentration in ruminal fluid increased over time from days 0 to $3(\mathrm{P}<0.05)$ but was not different between days 3 and 28 at any time $(\mathrm{P}>0.10)$ (Table 3$)$. In the $\mathrm{E}+$ treatment, ergovaline was present in the diet at $1.153 \mu \mathrm{mol} / \mathrm{day}$, was not detectable in the urine and had a faecal concentration of $0.408 \mu \mathrm{mol} /$ day (Table 4). Lysergic acid was detected in the diet of the $\mathrm{E}+$ treatment at $0.155 \mu \mathrm{mol} / \mathrm{day}$, in the urine at 0.213 $\mu \mathrm{mol} / \mathrm{day}$, and in the faeces at $0.174 \mu \mathrm{mol} / \mathrm{day}$ (Table 4). From these data, we determined that approximately $35 \%$ of dietary ergovaline and $248 \%$ of dietary lysergic acid were recovered in the faeces and urine (Table 4). The appearance of lysergic acid in the faeces and urine in greater amounts than in the feed implies that the ergot alkaloids in the feed were degraded to lysergic acid by ruminal microbial digestion and/or degradation in the lower gastrointestinal tract. However, research investigating degradation of ergot alkaloids in the lower digestive tract has not been conducted and is the subject of future research.

\section{Hepatic in Vitro Metabolism of Ergotamine in Mouse Liver Microsomes}

In vitro metabolism of the ergot alkaloid ergotamine in mouse liver microsomes was characterised by LC-MS/MS (Duringer et al. 2005). Nine peaks were identified by HPLC with retention times of approximately 17, 20, 22, 24, 25, 26.5 (ergotamine), $31,33.5$ and $35 \mathrm{~min}$. A standard solution of ergotamine gave an HPLC peak at approximately $26.5 \mathrm{~min}$. The ergotamine standard solution several days after preparation showed a new peak with a retention time of approximately $35 \mathrm{~min}$. The mass spectra of the collected 26.5-min (Fig. 2A) and 35-min (Fig. 2B) components both showed a pseudomolecular ion at $\mathrm{m} / \mathrm{z} 582[\mathrm{M}+\mathrm{H}]^{+}$and a fragment ion at $\mathrm{m} / \mathrm{z} 564\left[\left(\mathrm{M}-\mathrm{H}_{2} \mathrm{O}\right)+\mathrm{H}\right]^{+}$due to loss of water.

The mass spectra of components that eluted at approximately 24 (M2), 25 (M1), 31 (M2e) and 33.5 (M1e) min all showed a pseudomolecular ion at $\mathrm{m} / \mathrm{z} 598[\mathrm{M}+\mathrm{H}]^{+}$(Fig. 2C). This is 16 mass units greater than ergotamine, consistent with oxidation of the molecule. The daughter ion spectra of the pseudomolecular ion $\mathrm{m} / \mathrm{z} 598$ for the hydroxylated metabolites gave fragment ions of $\mathrm{m} / \mathrm{z} 580$ and 223, 208 and 268 (Fig. 2D-F). The $\mathrm{m} / \mathrm{z}$ of the 580 ion fragment is consistent with loss of water from the molecule $\left[\left(\mathrm{M}-\mathrm{H}_{2} \mathrm{O}\right)+\mathrm{H}\right]^{+}$, and fragmentation at $\mathrm{m} / \mathrm{z} 223$ is consistent with the lysergic ring system without the carboxyl group at $\mathrm{C} 8$. These spectra showed additional fragment ions at $\mathrm{m} / \mathrm{z} 268$, consistent with protonation of lysergic acid, and $\mathrm{m} / \mathrm{z} 208$, consistent with demethylation of the $\mathrm{m} / \mathrm{z} 223$ ion $\left[\mathrm{m} / \mathrm{z} 223-\mathrm{CH}_{3}\right]$. The presence of these lysergic acid ring groups suggests that the hydroxylation of ergotamine is not taking place on the lysergic acid ring portion of the molecule but on the peptide ring structure.
The mass spectra of components that eluted at approximately 17 (M3), 20 (M4) and 22 (M5) min all showed a pseudomolecular ion at $\mathrm{m} / \mathrm{z} 614[\mathrm{M}+\mathrm{H}]^{+}$(Fig. 2G). These metabolites are 32 mass units greater than ergotamine, consistent with dihydroxylation. The daughter ion spectra of the $\mathrm{m} / \mathrm{z} 614$ pseudomolecular ion for the dihydroxylated metabolites produced fragment ions at $\mathrm{m} / \mathrm{z}$ 596, 223, 208 and 268 (Fig. $2 \mathrm{H}-\mathrm{I}$ ). The $\mathrm{m} / \mathrm{z}$ of 596 is consistent with loss of water from dihydroxylated ergotamine $\left[\left(\mathrm{M}-\mathrm{H}_{2} \mathrm{O}\right)+\mathrm{H}\right]^{+}$. The other $\mathrm{m} / \mathrm{z}$ signals $(223,208$ and 268$)$ have been described above and again suggest that hydroxylation is taking place on the peptide portion of the molecule.

\section{Conclusions}

The characterisation of ergot alkaloids present in grass samples by mass spectrometry has presented a clearer picture of the varying array of these compounds present in tall fescue and perennial ryegrass forage. It is hypothesised that ergot alkaloids other than ergovaline may contribute to cases of fescue toxicosis so attempts to correlate the appearance of these compounds with clinical cases need to be made. Knowledge as to their roles in the etiology of fescue toxicosis will need to be examined as well.

The information reported on the ruminal metabolism of ergovaline to lysergic acid in sheep fed endophyte-infected straw is the first attempt to quantify these specific alkaloids in the body fluids examined. These data allowed us to propose a preliminary model of ergopeptide degradation and absorption from the digestive tract as follows: where the alkaloids are liberated from the digestible fraction of the diet, ergovaline is degraded to lysergic acid by microbial action. Alkaloids in the rumen fluid are then absorbed across the rumen wall. Once in the blood stream, the alkaloids flow to the liver. In the liver, it is likely that there is additional degradation and alteration of the alkaloids. Research shown here using mouse liver microsomes indicates conversion of ergot alkaloids to mono- and dihydroxylated metabolites. Further processing by the liver produces smaller alkaloids such as lysergic acid which are excreted via the urine. Larger alkaloids are excreted in the faeces via the bile. In addition, the faeces would also contain the fraction of alkaloids, both ergopeptides and ergolines, found in the indigestible portion of the feed. Further studies on the metabolism of ergovaline, other ergot alkaloids and their metabolites in the rumen, digestive tract and liver are needed to fully understand the contribution of each compound to eliciting fescue toxicosis. Lastly, studies have just begun on identifying genes that are up- and down-regulated in laboratory animals ingesting endophyte-infected feed using microarrays (Jones et al. 2004; Bhusari et al. 2006; Settivari et al. 2006). These studies need to be conducted in livestock species, on arrays designed from genetic material of that species, and is one of the current topics of research in our lab. All of this information will ultimately aid in the management of feeding endophyte-infected straw to livestock.

\section{ACKNOWLEDGEMENTS}

This paper is based upon work supported by the Oregon Agriculture Experiment Station and the U.S. Department of Agriculture under Agreement No. 58-6227-4-0021. Any opinions, findings, conclusion or recommendations expressed in this publication are those of the author(s) and do not necessarily reflect the view of the U.S. Department of Agriculture.

\section{REFERENCES}

Bacon, C.W. 1988. Procedure for isolating the endophyte from 
tall fescue and screening isolates for ergot alkaloids. Applied and Environmental Microbiology 54: 2615-2618.

Ball, S.E., Maurer, G.; Zollinger, M.; Ladona, M.; Vickers, A.E.M. 1992. Characterization of the cytochrome P-450 gene family responsible for the $\mathrm{N}$-dealkylation of the ergot alkaloid CQA 206-291 in humans. Drug Metabolism and Disposition 20: 56-63.

Bhusari, S.; Hearne, L.B.; Spiers, D.E.; Lamberson, W.R.; Antoniou, E. 2006. Effect of fescue toxicosis on hepatic gene expression in mice. Journal of Animal Science 84: 1600-12.

Browning, R. J. 2004. Effects of endophyte-infected tall fescue on indicators of thermal status and growth in Hereford and Senepol steers. Journal of Animal Science 82: 634-643.

Cheeke, P. 1995. Endogenous toxins and mycotoxins in forage grasses and their effects on livestock. Journal of Animal Science 73: 909-918.

DeLorme, M.; Lodge-Ivey, S.; Craig, A.M. 2007. Metabolism characterization and determination of physiological and digestive effects on lambs fed Neotyphodium coenophilauminfected tall fescue. Journal of Animal Science Accepted.

Duringer, J.; Estill, C.; Craig, A. 2007. Characterization of a new compound eluting in an ergovaline HPLC assay associated with reproductive problems in dairy cows. Proceedings of the 7th International Symposium on Poisonous Plants

Duringer, J.M.; Lewis, R.; Kuehn, L.; Fleischmann, T.; Craig, A.M. 2005. Growth and hepatic in vitro metabolism of ergotamine in mice divergently selected for response to endophyte toxicity. Xenobiotica 35: 531-48.

Hoveland, C.S. 1993. Importance and economic significance of the Acremonium endophytes to performance of animals and grass plant. Agriculture, Ecosystems and Environment 44: 312.

Jaussaud, P.; Durix, A.; Videmann, B.; Vigie, A.; Bony, S. 1998. Rapid analysis of ergovaline in ovine plasma using high-performance liquid chromatography with fluorimetric detection. Journal of Chromatography A 815: 147-53.

Jones, K.L.; King, S.S.; Iqbal, M.J. 2004. Endophyte-infected tall fescue diet alters gene expression in heifer luteal tissue as revealed by interspecies microarray analysis. Molecular Reproduction and Development 67: 154-61.

Joost, R. 1995. Acremonium in fescue and ryegrass: boon or bane? A review. Journal of Animal Science 73: 881-888.

Kanto, J. 1983. Clinical pharmacokinetics of ergotamine, dihydroergotamine, ergotoxine, bromocriptine, methysergide, and lergotrile. International Journal of Clinical Pharmacology and Therapeutic Toxicology 21: 135-42.

Lane, G.; Ball, O.; Davies, E.; Davidson, C. 1997. Ergovaline distribution in perennial ryegrass naturally infected with endophyte. pp. 65-67. In: Neotyphodium/Grass Interactions. Eds. Bacon, C.W.; Hill, N.S. Plenum Press, New York.

Lehner, A.F.; Fannin, N.; Bush, L.; Craig, M.; Tobin T. 2004. Fragmentation patterns of selected ergot alkaloids by electrospray tandem quadrupole mass spectrometry. Journal of Mass Spectrometry 39: 1275-1286.

Lehner, A.F.; Craig, A.M.; Fannin, N.; Bush L.; Tobin, T. 2005. Electrospray $[+]$ tandem quadrupole mass spectrometry in the elucidation of ergot alkaloids chromatographed by HPLC: screening of grass or forage samples for novel toxic compounds. Journal of Mass Spectrometry 40: 1484-1502.

Mas-Chamberlin, C.; Bromet, N.; Olgiati, V.; Girardello, R.; Lowenthal, D.T. 1997. Metabolism study of dihydro-alphaergocryptine, $9,10-\left[9,10-{ }^{3} \mathrm{H}(\mathrm{N})\right]$ in rat and human hepatocyte cultures and rat, monkey, and human microsomes. American Journal of Therapeutics 4: 291-9.

Maurer, G.; Schreier, E.; Delaborde, S.; Loosli, H.R.; Nufer, R.; Shukla, A.P. 1982. Fate and disposition of bromocryptine in animals and man. I. Structure elucidation of the metabolites. European Journal of Drug Metabolism and Pharmacokinetics 7: 281-292.

Maurer, G., Schreier, E.; Delaborde, S.; Loosli, H.R.; Nufer, R.; Shukla, A.P. 1983. Fate and disposition of bromocryptine in animals and man. II. Absorption, elimination and metabolism. European Journal of Drug Metabolism and Pharmacokinetics 8: $51-62$.

Moubarak, A.S.; Rosenkrans, C.F.J. 2000. Hepatic metabolism of ergot alkaloids in beef cattle by cytochrome P450. Biochemical and Biophysical Research Communications 274: 746-749.

Oliver, J.W. 2005. Pathophysiologic response to endophyte toxins. pp. 291-304. In: Neotyphodium in cool-season grasses. Eds. Roberts, C.A.; West C.P.; Spiers D.E. Blackwell Publishing, Ames, Iowa.

Oregon Agricultural Information Network. 2006. Commodity data sheet: Grass and legume seeds. http://oregonstate.edu/ oain/. Extension Economic Information Office, Oregon State University, Corvallis Oregon.

Porter, J. 1995. Analysis of endophyte toxins: fescue and other grasses toxic to livestock. Journal of Animal Science 73: 871-880.

Ronca, F.; Guazzelli, M.; Salvadori, P.; Palumbo, R.; Neuteboom, B.; Ambrosoli, L.; Poli, A Girardello, R.; Lowenthal D.T. 1996. Pharmacokinetic and Metabolism Study in Healthy Volunteers After Administration of Single Oral Dose of ${ }^{3} \mathrm{H}$ alpha-Dihydroergocryptine Mesylate. American Journal of Therapeutics 3: 553-562.

Settivari, R.S.; Bhusari, S.; Evans, T.; Eichen, P.A.; Hearne, L.B.; Antoniou, E.; Spiers, D.E. 2006. Genomic analysis of the impact of fescue toxicosis on hepatic function. Journal of Animal Science 84: 1279-1294.

Shelby, R.A.; Olsovska, J.; Havlicek, V.; Flieger, M. 1997. Analysis of ergot alkaloids in endophyte-infected tall fescue by liquid chromatography/electrospray ionization mass spectrometry. Journal of Agricultural and Food Chemistry 45: 4674-4679.

Yates, S.G.; Powell, R.G. 1988. Analysis of ergopeptine alkaloids in endophyte-infected tall fescue. Journal of Agriculture and Food Chemistry 36: 337-340. 